\section{The War on Women: And the Brave Ones Who Fight Back}

Sue Lloyd-Roberts. London, UK: Simon \& Schuster, 2016. ISBN-13: 978-1-471-15390-7. Price: $£ 16.00$. Pages: 320 (hardcover)

Not long after the author's death (the journalist, Sue Lloyd-Roberts) in October 2015, I heard her daughter speaking about this book on Radio 4. The ideas behind the book, and its aim to report on the experiences of women worldwide, sounded compelling. However, I was apprehensive that reading the book would prove too disturbing. It is shocking, but also extraordinary, and I could not put it down.

Sue Lloyd-Roberts writes transparently, based on the interviews that she conducted. Each chapter begins with a story told by an individual, an 'ordinary woman', illustrating her life experience. I suspect that elements of these stories will resonate with many people around the world, and with clinicians working in sexual and reproductive health in particular. The book highlighted to me the daily struggle of existence for so many, which is relevant to all of us in our globalised society, but also described the extraordinary bravery of the individuals whom the author interviewed.

The book starts with female genital mutilation (FGM) in the UK, and offers some background to the practice and the recent changes in reporting policies for clinicians, as well as touching on the only UK FGM trial of a medical practitioner. Subsequent chapters address other events in recent history: Argentina and its dirty wars in the 1970s, the Magdalene laundries in Ireland; and then moves on to more current events, Egypt and Tahrir square, sex trafficking, forced marriage and sexual assault in the wars in Bosnia and the Democratic Republic of the Congo.

There are themes of societal attitudes, sexual assault and a lack of access to reproductive choices, which underline every story. The analysis of actions that, at first glance, appear inexplicable is invaluable for those readers whose personal experiences may be very different. The motivation of the perpetrators is considered in a way that challenges the reader to view situations from a different perspective, while the fortitude shown by those who stand up to their wrongdoers serves as a powerful example of the ways in which accepted attitudes can be questioned and overturned.

Interestingly the book ends as it begins, in the UK. Sue Lloyd-Roberts cleverly draws attention to pervasive attitudes even 'at home' by considering sex inequality in the UK. Do read this book. You may find it difficult at the time, but ultimately I suspect you will not regret doing so.

Reviewed by Shamela de Silva

Consultant in Genitourinary Medicine and HIV, West Middlesex Hospital, London, UK; shamela.desilva@nhs.net

Competing interests None declared.

Provenance and peer review Not

commissioned; internally peer reviewed.

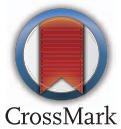

Published Online First 28 November 2016

J Fam Plann Reprod Health Care 2017;43:83.

doi:10.1136/jprhc-2016-101675 